\title{
Ks. Krzysztof Graczyk, Wpływ schorzeń neurologicznych na zdolność do podjęcia istotnych obowiązków matżeńskich, Włocławek 2014, 326 ss.
}

Przedmiot publikacji ks. K. Graczyka Wpływ schorzeń neurologicznych na zdolność do podjęcia istotnych obowiązków małżeńskich, stanowią schorzenia neurologiczne jako przyczyna niezdolności do realizacji podstawowych obowiązków małżeńskich i podstawa w procesie kościelnym o stwierdzenie nieważności małżeństwa.

Analizując przedstawioną problematykę badawczą, czytelnik może stanąć przed pytaniem: jaki może być motyw i podstawa dla podjęcia problematyki w tak określonym wariancie przez autora? Taki bowiem szczególny aspekt badań prawno-kanonicznych kieruje w dużej mierze uwagę na ukierunkowane zainteresowania medyczne i pogłębione zainteresowania psychologiczno-pedagogiczne. Szukając odpowiedzi na to pytanie, zainteresowałem się bliżej curriculum vitae Autora publikacji, z którego się dowiedziałem, iż jego wczesne zainteresowania studiami medycznymi przetrwały w nim i po ukończeniu studiów teologicznych, a następnie studiów w zakresie prawa kanonicznego, i po uzyskaniu doktoratu z prawa kanonicznego na KUL-u, ks. K. Graczyk nawiązał bliskie kontakty z naukowym środowiskiem medycznym i z osobami chorymi. Sam uczęszczał najpierw na wybrane zajęcia w Akademii Medycznej w Lublinie i tam jako wolontariusz udzielał się czynnie w Stowarzyszeniu Chorych na Sclerosis Multiplex, co umożliwiło mu bliższy kontakt z osobami chorymi i zapoznanie się ze skutkami wielu chorób neurologicznych. Analogiczna sytuacja stała się jego udziałem na Katolickim Uniwersytecie Lubelskim, gdzie uczęszczał na wykłady z psychologii klinicznej, a to z kolei umożliwiło 
mu nawiązanie bliższego kontaktu naukowego z profesorami $\mathrm{z}$ tej dyscypliny naukowej.

Moim zdaniem tu należy szukać inspiracji Autora omawianej publikacji w jego badaniach nad teologią i prawno-kanonicznym wymiarem małżeństwa $\mathrm{w}$ aspekcie problemów osobowościowych kandydata, czy kandydatów do zawarcia związku małżeńskiego.

Podjęta do recenzji publikacja ks. K. Graczyka, oprócz wstępu i zakończenia obejmuje pięć rozdziałów. W rozdziale pierwszym Autor koncentruje uwagę na pojęciu osobowości, aby na jego tle ukazać zaburzenia osobowości powodowane chorobami układu nerwowego. W rozdziale drugim wychodzi on od personalistycznego ujęcia małżeństwa, jako pełnej i trwałej wspólnoty życia między osobami, którą Konstytucja ostatniego Soboru Gaudium et spes, tak definiuje: "Głęboka wspólnota życia i miłości małżeńskiej, ustanowiona przez Stwórcę i unormowana Jego prawami, zawiązuje się przez przymierze małżeńskie, czyli przez nieodwołalną osobistą zgodę. W ten sposób aktem osobowym, poprzez który małżonkowie wzajemnie się sobie oddają i przyjmują, powstaje $z$ woli Bożej instytucja trwała także wobec społeczeństwa" (GS, 48; por. Monografia, s. 62).

Komentując to kościelne określenie instytucji małżeństwa Autor monografii zwraca uwagę na cele tak rozumianego małżeństwa, którymi są: dobro samych małżonków, dobro potomstwa i dobro społeczne. Tak rozumiane dobro jest wynikiem zgody małżeńskiej. Zatem sama zgoda małżeńska musi być aktem wolnym i świadomym, czyli aktem w pełni ludzkim. Stąd też brak pełnego rozeznania w zakresie istotnych praw i obowiązków małżeńskich u którejś ze stron zawierających małżeństwo stanowi podstawę nieważności małżeństwa z prawa naturalnego. W takiej sytuacji KPK orzeka: „Niezdolni do zawarcia małżeństwa są ci, którzy mają poważny brak rozeznania oceniającego co do istotnych praw i obowiązków małżeńskich wzajemnie przekazywanych i przyjmowanych" (KPK, kan. 1095, n. 2).

Ponieważ ten przepis ogólny natrafia na pewne trudności w jego zastosowaniu do konkretnych przypadków w sprawach wnoszonych do trybunałów kościelnych, wymaga on pogłębionej analizy wady zgody małżeńskiej w konkretnych przypadkach. Szczegółowa analiza 
takich przypadków została podjęta w paragrafach 1-3, II-go rozdziału omawianej monografii (s. 62-124). We wniosku wyprowadzonym $\mathrm{z}$ analizy wielu konkretnych przypadków Autor monografii stwierdza, że każdy wniosek o orzeczenie nieważności małżeństwa z przyczyn powodujących zaburzenia osobowości chorobami układu nerwowego wymaga dokładnej analizy medycznej, psychologicznej i środowiskowej każdej konkretnej osoby, której „uogólnianie” byłoby niewłaściwe $\mathrm{z}$ racji indywidualnego przeżywania konkretnych problemów przez każdego z nas. Ponadto, przy orzekaniu niezdolności do podjęcia obowiązków małżeńskich chodzi zdecydowanie o obowiązki istotne a nie drugorzędne (np. różnica charakterów, różnica wychowania, odmienna uczuciowość partnerów, itd.). Niezdolność powinna mieć miejsce już w akcie wyrażania zgody, z którą związane jest zobowiązanie podjęcia istotnych obowiązków. W tym kontekście należy się upewnić, czy akty wykonywane przez małżonków po zawarciu małżeństwa wykazują nieprawidłowości przed małżeństwem i uniemożliwiają wykonywanie obowiązków istotnych, czy są po prostu świadomym i dobrowolnym naruszeniem przyjętych obowiązków (por. s. 125-131).

W oparciu o dokładnie przeprowadzone indywidualne badania medyczne i psychologiczne stron można właściwie ustalić prawdziwość zaburzeń neurologicznych jako przyczynę nieważności małżeństwa. Temu problemowi jest poświęcony trzeci rozdział monografii ks. K. Graczyka: Zaburzenia neurologiczne jako przyczyna nieważności małżeństwa. Zgodnie z zasadą o celu małżeństwa zorientowanym na dobro obu stron i dobro potomstwa, jeśli ten cel zostaje wykluczony przez którąś ze stron wówczas małżeństwo z natury jest nieważne. Wśród przyczyn powodujących nieważność małżeństwa Autor publikacji wymienia: wykluczenie dobra małżonków, dobra potomstwa, impotencję, podstępne wprowadzenie w błąd. W kontekście tych zjawisk następuje zachwianie jedności duchowej stron w małżeństwie, nieprawidłowe relacje wzajemnej pomocy, zakłócenia intymnego pożycia małżonków, psychiczna bariera miłości wzajemnej, niezdolność dokonania stosunku małżeńskiego. 
Analiza treści przedstawionej przez Autora publikacji zwraca uwagę, iż przyczyna $w$ nieprawidłowościach unieważniających małżeństwo nie ma wyłącznie uzasadnienia medycznego czy psychicznego, ale również w przypadku małżeństwa sakramentalnego w Piśmie św. są wskazania do służenia przez małżonków wzajemną sobie pomocą: „Nie jest dobrze, żeby mężczyzna był sam: uczynię mu zatem odpowiednią dla niego pomoc" ( $\mathrm{Rdz} 2,18)$. To przesłanie biblijne ma na uwadze szeroki zakres możliwej pomocy wzajemnej, zarówno duchowej, osobistej, rodzinnej i zawodowej, a ta przenosi się także na płaszczyznę społeczną, na jakiej plasuje się małżeństwo. Tego rodzaju przesłanka, mimo jej źródła biblijnego, nie ma jedynie charakteru religijnego, bo w przypadku choroby neurologicznej trudno jest wymagać wzajemnej pomocy stron w małżeństwie. Oczywiście nie można dogmatyzować twierdzenia, że zakłócenia współżycia rodzinnego muszą prowadzić do rozpadu życia małżeńskiego i rodzinnego, ale narażają na takie niebezpieczeństwo i uniemożliwiają realizację celów małżeństwa, wśród których jest wzajemna pomoc zorientowana na wspólne dobro. Wchodząc głębiej w charakter przyczyn nieważności małżeństwa z powodu zaburzeń neurologicznych można dostrzec, że jakkolwiek w procesie kościelnym nie można opierać się zasadowo na przesłaniu biblijnym o „wzajemnej pomocy” małżonków, to trzeba przyznać, że to przesłanie stanowi ważną podbudowę do oceny zobowiązań stron zawierających małżeństwo. Innymi słowy, także w tej materii całkowicie naturalnej ma zastosowanie przesłanka natury religijnej.

W logicznym związku z rozdziałem ogólnie traktującym o przyczynach nieważności małżeństwa z powodu zaburzeń neurologicznych pozostaje rozdział czwarty monografii, w którym Autor omawia Skutki zaburzeń neurologicznych jako ograniczenie zdolności do zawarcia matżeństwa.

Cały przewód myślowy w tym rozdziale jest oparty na podstawowej tezie, która mówi, że zgoda matżeńska będaca przyczyna sprawcza zaistnienia małżeństwa, zakłada wolność woli oraz zdolność używania rozumu i pewna dojrzałość sądu. Skoro przedmiotem umowy małżeńskiej jest trwała i wyłączna wspólnota życia, zorientowana 
na dobro osobiste małżonków i potomstwa zeń zrodzonego, to zakres niezdolności do podjęcia istotnych obowiązków małżeńskich pokrywa się z zakresem przedmiotu zgody (por. s. 191). To ustalenie stanowi bazę całego rozważania Autora w tym rozdziale rozprawy prowadząc do wniosku, że brak właściwego rozeznania w zakresie istotnych praw i obowiązków małżeńskich i niezdolność do ich podjęcia, uwarunkowana przyczynami natury psychicznej, stanowi podstawę nieważności małżeństwa. Do ważności małżeństwa nie wystarczy zatem samo rozeznanie wymogów zgody małżeńskiej, ale konieczna jest zdolność do podjęcia istotnych obowiązków wynikających z tej zgody. Niezdolność do podjęcia i realizacji istotnych obowiązków wynikających ze zgody małżeńskiej może być wieloraka: niezdolność do intymnego pożycia małżeńskiego, patologiczna wręcz niechęć do zrodzenia dziecka, niezdolność do wychowania dziecka, niezdolność do tworzenia wspólnoty życia w sferze fizycznej i duchowej (por. s. 230-233).

Ostatni rozdział Wnioski i postulaty prawno procesowe, zgodnie $\mathrm{z}$ jego sformułowaniem zawiera syntezę postępowania procesowego w sprawie o ustalenie nieważności małżeństwa z przyczyn chorób nerwowych. Po dość obszernej analizie postępowania czysto prawnego, Autor rozprawy jako kanonista uwzględnia też wnioski duszpasterskie związane z procesem. W tym aspekcie wydaje się ważna uwaga, że celem procesu kościelnego nie jest rozwiązanie małżeństwa, bo to zakładałoby jego uprzednią ważność, ale stwierdzenie jego nieważności od początku (por. s. 262). To stwierdzenie jest ważne w sensie duszpasterskim, bo eliminuje traktowanie stwierdzenia nieważności na równi z rozwodem, właściwym dla orzeczeń prawno-cywilnych.

Jak ocenić wartość monografii habilitacyjnej ks. Krzysztofa Graczyka?

Jakkolwiek publikacja ks. K. Graczyka nosi styl całkowicie prawniczy, zgodnie z omawianą problematyką, to nie brakuje w niej również odniesień duszpasterskich, które w tej materii posiadają ważne znaczenie dla kościelnej i parafialnej formacji duchowej wiernych. Ten fakt jednoznacznie potwierdza interdyscyplinarny wymiar małżeństwa w jego aspekcie sakramentalnym, a tym samym prawo obu 
autonomicznych dyscyplin, jakimi są prawo i teologia, do prowadzenia badań w zakresie problematyki dotyczącej małżeństwa. Śledząc całe postępowanie kościelnych trybunałów sądowych w sprawie ustalenia nieważności małżeństwa z przyczyn naturalnych, da się w nim dostrzec także motyw wiary oraz troskę o dobro duchowe stron w związku małżeńskim, sakralny charakter małżeństwa i troskę o godność osoby ludzkiej.

W tym wymiarze widzę wartość opublikowanej monografii ks. Krzysztofa Graczyka, który prezentując problem o charakterze prawnym potrafi umiejętnie zauważyć w nim i wydobyć na światło dzienne także aspekt teologiczno-duszpasterski. Stanowi to pozytywny dowód zastosowania odpowiedniej wiedzy teologicznej Autora w jego formację prawniczą, uzupełnioną wystarczającą znajomością niektórych zagadnień z postępowania psychologiczno-medycznego, nabytego przez Autora monografii w odpowiednich wykładach uniwersyteckich i kontaktach ze światem nauki w tym zakresie. Widać jednocześnie dobrze rozwinięty zmysł praktyczny u Autora tej publikacji, nabyty w jego kontaktach $\mathrm{z}$ chorymi i w sądowniczej praktyce prowadzonej przez niego samego.

Omawiana tu monografia ma charakter opracowania w pełni źródłowego. Jej Autor oparł się na podstawowych źródłach stanowionych przez: Dokumenty Kościoła Powszechnego, Dokumenty papieskie, Dokumenty Papieskiej Komisji dla Rewizji Kodeksu Prawa Kanonicznego, a także w aspekcie sakramentalnego wymiaru małżeństwa stanowione przez Pismo św. Bardzo cenny jest wykorzystany przez ks. K. Graczyka materiał przewodowy i dowodowy z wyroków Roty Rzymskiej w kwestiach schorzeń neurologicznych. Bogata jest również literatura przedmiotu ściśle prawno-kanoniczna, rozbudowana obszerną przedmiotową literaturą teologiczną, literaturą z zakresu psychologii i medycyny. Tym samym Autor przeprowadzonych badań, odnotowanych w monografii, wskazał na małżeństwo jako interdyscyplinarny przedmiot badań i wyraził własną świadomość w tej materii. 